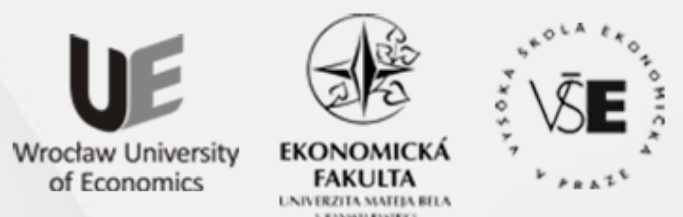

Conference Proceedings

Full TeXT PAPERS

edited by

Zofia Rusnak and Beata Zmyślona

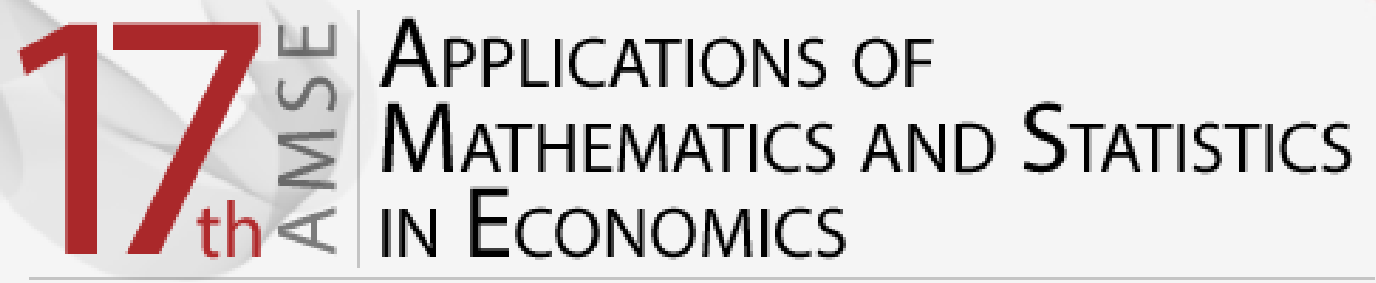

International Scientific Conference | Poland • 27-31 August 2014 
Scientific Committee

Richard Hindls, Stanislava Hronová, Rudolf Zimka, Walenty Ostasiewicz, Emília Zimková, Zofia Rusnak, Martin Bod'a

Organizing Committee

Beata Zmyślona, Cyprian Kozyra, Grzegorz Rogoziński, Kristýna Vltavská

\section{Reviewers}

Milan Bašta, Diana Bílková, Martin Bod'a, Joanna Dębicka, Tomáš Fiala, Jakub Fischer, Stanisław Heilpern, Karel Helman, Lenka Hudrlíková, Miroslav Hužvár, Nikola Kaspř́ková, Alena Kaščáková, Kamil Kladívko, Jindřich Klůfa, Pavol Král', Katarzyna Kuziak, Jana Langhamrová, Ivana Malá, Tomáš Marcinko, Luboš Marek, Miloš Maryška, Petr Mazouch, Zofia Mielecka-Kubień, Witold Miszczak, Petr Musil, Gabriela Nedelová, Walenty Ostasiewicz, Iva Pecáková, Viera Roháčová, Zofia Rusnak, Mária Stachová, Jana Špirková, Šárka Šustová, Jana Tepperová, Vladimír Úradníček, Kristýna Vltavská, Michal Vrabec, Dariusz Wawrzyniak, Henryk Zawadzki, Jaroslav Zbranek, Tomáš Zeithamer, Martin Zelený, Jan Zeman, Rudolf Zimka, Emília Zimková, Pavel Zimmermann, David Žižka

Layout

Martin Bod'a, Beata Zmyślona, Grzegorz Rogoziński

Front page design

Grzegorz Rogoziński

CD cover design

Beata Dębska

Articles published in the form submitted by the authors

All rights reserved. No part of this book may be reproduced in any form or in any means without the prior permission in writing of the Publisher

(C) Copyright by Wrocław University of Economics Wrocław 2014

ISBN 978-83-7695-421-9

Wydawnictwo Uniwersytetu Ekonomicznego we Wrocławiu

53-345 Wrocław, ul. Komandorska 118/120 www.ue.wroc.pl

Sprzedaż książek tel./fax 71 36-80-602

e-mail: econbook@ue.wroc.pl www.ksiegarnia.ue.wroc.pl 


\section{Contents}

Foreword

Diana Bílková: TL-Moments: Analogy of Classical L-Moments

Dagmar Blatná: Application of Robust Regression in the Analysis of Internet Access in European Countries

Martin Bod’a, Mária Kanderová: Rebalancing Issues in Tracking Error Variance Minimization

Martin Bod'a, Viera Roháčová: Application of Six Sigma Ideas to Timing Decisions at Financial Markets

Anton Dekrét, Rudolf Zimka: On the Price Hartwick's Task and Its Inverse in a Dynamic Model of an Economy with Exhaustible Resources

Joanna Dębicka, Agnieszka Marciniuk: Comparison of Reverse Annuity Contract and Reverse Mortgage on the Polish Market.

Petra Dotlačilová, Jitka Langhamrová: The Influence of Mortality Models for the Expected Future Life-time of Older People

Marek Ďurica, Lucia Švábová: Delta and Gamma for Chooser Options.

Vlastimil Farkašovský: New Concept of Pension Funds Performance Evaluation

Albert Gardon: The Normality of Weekly Relative Changes of the Freight Rate in Container Shipping.

Mária Grausová, Miroslav Hužvár, Jana Štrangfeldová: Healthcare Systems Efficiency in the Visegrád Group.

Stanisław Heilpern: Multiple Life Insurance - Pension Calculation

Alena Kaščáková, Gabriela Nedelová: Changes in Slovak Households' Economy

Igor Kollár, Pavol Král', Peter Laco: Methodology for Assessing Website Improvement in Corporate Environment.

Maciej Kostrzewski: Some Method of Detecting the Jump Clustering Phenomenon in Financial Time Series.

Cyprian Kozyra, Beata Zmyślona, Katarzyna Madziarska: Complementary Objective and Subjective Measures of Hospital Services Quality...

Pavol Král', Mária Stachová, Lukáš Sobíšek: Utilization of Repeatedly Measured Financial Ratios in Corporate Financial Distress Prediction in Slovakia

Ivana Malá: The Use of Finite Mixture Model for Describing Differences in Unemployment Duration

Lukáš Malec: Studying Economics and Tourism Industry Relations by Smooth Partial Least Squares Method Depending on Parameter. 
Tomáš Marcinko: Consequences of Assumption Violations Regarding Classical Location Tests.

Edyta Mazurek: The Income Tax Progression Depending on Social Insurance Contribution in Poland.

Petr Musil, Jana Kramulová, Jan Zeman: Regional Consumption Expenditures: An Important Starting Point for Regional Input-output Tables.

Katarzyna Ostasiewicz, Walenty Ostasiewicz: Good Life: From Political to Human Economy

Anna Sączewska-Piotrowska: Analysis of Poverty Transitions in Poland Using Multilevel Discrete-Time Event History Models

Martina Šimková, Petra Švarcová: Disadvantaged University Students in the Czech Republic.

Michal Široký: The Use of Short-term Business Statistics for Quarterly GDP Flash Estimates in the Czech Republic

Zdeněk Šulc, Hana Řezanková: Evaluation of Recent Similarity Measures for Categorical Data.

Lucia Švábová, Marek Ďurica: The Relationship Between the Finite Difference Method and Trinomial Trees

Kristýna Vltavská, Jaroslav Sixta: The Estimation of Final Consumption Expenditures

Lenka Vraná: Business Cycle Analysis: Tracking Turning Points

Janusz Wywiał: On Bayesian Testing in Auditing

Emília Zimková: Window Analysis of Supper-efficiency Change: Case of the Slovak Banking System ....

Beata Zmyślona: Statistical Modelling of the Impact of Diabetes on the Risk of Hospitalization 


\title{
ANALYSIS OF POVERTY TRANSITIONS IN POLAND USING MULTILEVEL DISCRETE-TIME EVENT HISTORY MODELS ANNA SACZEWSKA-PIOTROWSKA
}

University of Economics in Katowice, Faculty of Economics, Department of Statistical and

Mathematical Methods in Economics, ul. Bogucicka 14, 40-226 Katowice, Poland email: anna.saczewska-piotrowska@ue.katowice.pl

\begin{abstract}
Poverty analysis is carried out mostly in cross-sectional terms. Enriching analysis with time factor allows to reply questions about changes in poverty over a period. In the long run units (households, families, etc.) can entry and exit the poverty zone. Analysis of determinants of these changes can indicate a group of vulnerable households entering into the poverty zone and those which have the best chance of exiting from poverty.

The main objective of this paper is to identify determinants of poverty in time of transformation of Polish economy, in years 2000-2013. To achieve this aim, multilevel discrete-time event history logit models were used. Logit models of entering (exiting) poverty were estimated in two versions - the first variant includes the number of years spent outside poverty zone, while the second scenario includes also selected socio-economic characteristics of the household and the head of household (e.g. place of residence, sex and age of household's head).
\end{abstract}

Key words: poverty transitions, event history analysis, discrete-time models.

DOI: $10.15611 /$ amse.2014.17.24

\section{Introduction}

Poverty is usually analyzed in a static way. This way of analyzing the phenomenon does not allow to obtain a picture of poverty changes in the long term. Particularly important from the point of view of social policy is to identify groups of households at-risk of long-term poverty. These groups of households are often at-risk of social exclusion and biological degradation. For this reason, it is important to identify these households and to prevent longterm poverty.

The purpose of this article is to determine whether the length of time spent in (out of) poverty affect the ability of poverty exit (enter). The aim of the study is also to identify the characteristics of households and households' heads conductive entering and exiting from poverty. To achieve this aim, event history analysis models with discrete time were used. The dependent variable in event history analysis, which is also known as survival analysis, duration analysis or hazard modelling, is the duration until event occurrence. Outcome variable in our analysis is individual change in poverty status from one period to another (poverty entries and exits) which are called events. Periods between two poverty entries (exits) are called spells or episodes. Spell is also defined as waiting time for the occurrence of event (Frątczak, Gach-Ciepiela, Babiker, 2005, 23). A key quantity in survival analysis is hazard rate which can be interpreted as probability that an event (poverty entry or poverty exit) occurs during a very small interval of time $t$ given that no event has occurred in a previous interval (Steele, 2008). Hazard rates are calculated using only the population that is still at-risk of experiencing the event. Poverty entry or poverty exit may occur at any time, but 
the panel data are in discrete-time intervals, a discrete-time hazard model is more appropriate than a continuous-time hazard model (Jenkins, 2004). In analysis we used well-known discrete-time model, i.e. logit model.

\section{Data}

Study of poverty dynamics in Poland was based on seven waves of panel realized in years 2000-2013 in the framework of project "Social Diagnosis" (Council for Social Monitoring, 2014). In subsequent waves of the study involved all households from the previous wave and holding of a new representative sample. The analysis of the dynamics of poverty refers to households participating in any wave of the panel.

Poverty analysis adopted economic definition of poverty. As an indicator of households' wealth assumed net income of households in Poland in February 2000, 2003, 2005, 2007, 2009, 2011 and 2013. In order to take account the differences in a household's size and composition there was calculated equivalised income by dividing the household's income by its equivalent size, which was calculated using the modified OECD equivalence scale. This scale assigns 1 to the first adult of the household, 0.5 to each subsequent adult aged 14 or more and 0.3 to children (each person under 14). There were adopted household weighted equivalised income. Poverty threshold was set at $60 \%$ of the median equivalised income.

\section{Methodology}

\subsection{Discrete-Time Hazard Analysis for Recurrent Events}

Many events in economic or social research may occur more than once to an individual over the observation period. Households participating in panel in "Social Diagnosis" project could enter to poverty zone (or exit from poverty zone) several times, which means the events may be repeated.

Let $T_{i k}$ be a set of random variables representing the time at which the $k^{\text {th }}$ event occurs to individual $i$, and let $t_{i k}$ be the realized value of $T_{i k}$. The onset of risk for event $k$ is defined as the first time point after occurrence of event $k-1$ where a transition of status can take place. The discrete-time hazard rate for individual $i$ for the first event $(k=1)$ is then defined as (Callens, Croux, 2009)

$$
P_{i 1 t}=\operatorname{Pr}\left(T_{i 1}=t \mid T_{i 1} \geq t\right)
$$

and for subsequent events $(k=2,3, \ldots)$ has the form

$$
P_{i k t}=\operatorname{Pr}\left(T_{i k}=t \mid T_{i k} \geq t, T_{i 1}=t_{i 1}, T_{i 2}=t_{i 2}, \ldots, T_{i(k-1)}=t_{i(k-1)}\right) .
$$

The next step is to specify how this hazard depends on time and explanatory variables. The most popular choice is the logistic regression function (Iceland, 1997; McKernan, Ratcliffe, 2005; Stevens, 1999; Steele, 2011)

$$
P_{i k t}=\frac{1}{1+\exp \left(-\alpha(t)-\beta x_{i k t}-u_{i}\right)},
$$

which can also be written in logit form 


$$
\log \left(\frac{P_{i k t}}{1-P_{i k t}}\right)=\alpha(t)+\beta x_{i k t}+u_{i},
$$

where $P_{i k t}$ is the probability of an event during interval $t, x_{i k t}$ is a vector of covariates (time varying or defined at the episode or individual level), $\alpha(t)$ is some function of $t$, which we refer to as the baseline logit-hazard. For example, $\alpha(t)$ may take the form of linear or polynomial function. The most flexible form for $\alpha(t)$ is a step function which is specified by treating $t$ as a categorical variable. Time is treated as a dummy variable with the category specified for each time interval

$$
\alpha(t)=\alpha_{1 i} D_{1}+\alpha_{2 i} D_{2}+\ldots+\alpha_{s i} D_{s}
$$

where $D_{1}, D_{2}, \ldots, D_{s}$ are dummies for time intervals $t=1,2, \ldots, s$ and $s$ is the maximum observed event time. Vector of dummies for $t$ leads to a piecewise-constant hazard model. Individual-specific unobservables are represented by $u_{i}$, which is usually assumed to follow a normal distribution with mean zero and variance $\sigma^{2}$ (Steele 2011).

We can notice when events are repeatable, event history data have a two-level hierarchical structure with spells (level 1) nested within individuals (level 2). Thus repeated events may be analysed by using multilevel models. A random-effect logit model, which is also known as a shared-frailty model, takes a form (1). Using multilevel modelling terminology (1) is referred to as two-level random intercept model, because the transformed probability of an event in interval $t$ is shifted up or down by an amount $u_{i} \sim N\left(0, \sigma^{2}\right)$ for a given individual but the effects of duration and covariates are assumed to be constant across individuals (Steele, 2008, 2011).

\subsection{Estimation Procedures}

Random-effects models for recurrent events can be fitted using any multilevel modelling software, however packages vary in the estimation procedures used, leading to differences in parameter estimates. Models can be fitted using mainstream software (e.g. Stata, SAS) and specialist multilevel modelling software (e.g. MLwIN, SABRE). Model parameters can be estimated using maximum likelihood method (SAS, Stata, SABRE), quasi-likelihood methods (MLwIN) and Markov chain Monte Carlo (MCMC) methods (MLwIN). Some authors (Browne, Draper, 2006) draw attention to flexibility of MCMC methods and ability of extension MCMC to more complex problems, even with rather large data sets.

Logit models were estimated in MLwiN using $1^{\text {st }}$ order marginal quasi-likelihood (MQL-1), $2^{\text {nd }}$ order penalized quasi-likelihood (PQL-2) and MCMC methods. MQL and PQL methods are based on first- or second-order Taylor expansions. MQL involves expansion around the fixed part of the model, whereas PQL additionally includes the random part in its expansion (Hedeker, 2008). The PQL method generally gives better estimates than the MQL method, but is more prone to convergence problems and so a typical strategy is to try MQL estimation first and if this succeeds then move onto PQL estimation using the MQL estimates as starting values for the PQL procedure (Lawson, Browne, Vidal Rodeiro, 2003, 40). Results of the second order PQL are used as starting values in the MCMC Bayesian method. In MCMC sampling with multilevel models it is natural to use as starting values the likelihood and quasi-likelihood results from MQL/PQL in models (Browne, Draper, 2006). The Bayesian approach to statistics can be thought of as a sequential learning approach. In the Bayesian approach we wish to combine our prior beliefs/ideas with the data collected to 
produce new posterior beliefs/ideas about the problem (Browne, Rasbash, Charlton, 2012, 2). Then the previous posterior ideas act as prior knowledge and combined with data simulated from the joint posterior distribution using a sampler such as Metropolis-Hastings sampler. The following prior distributions were used for analysis:

- for fixed parameters $p(\beta) \propto 1$. This improper uniform prior is functionally equivalent to a proper Normal prior with variance $c^{2}$, where $c$ is extremely large with respect to the scale of the parameter,

- for scalar variances $p\left(\frac{1}{\sigma^{2}}\right) \sim \Gamma(\varepsilon, \varepsilon)$ with $\varepsilon=0,001$.

Deviance Information Criterion (DIC) was used as a measure of how well model fits the data. DIC is a generalization of the Akaike's Information Criterion (AIC). Models with smaller DIC should be preferred to models with larger DIC.

\subsection{Censoring Information}

In the analysis of poverty duration there are many situations in which the story of the episode is not complete - there is the problem of right and left censored data. This means that certain episodes start and end outside the period of the study. Figure 1 illustrates three possible situations of censoring. Line starts when household becomes at-risk of poverty and the black square represents the events. The first episode of household 1 starts outside observation period (left-censored observation), the third episode of household 2 ends outside observation period (right-censored observation) and the first episode of household 3 starts and ends outside observation period. Right-censoring is the most common form of censoring. Excluding right-censored observations leads to bias and may drastically reduce sample size (Steele, 2005). Left-censored observations are more problematic and therefore analysis takes into account the episodes that start within the observation period.

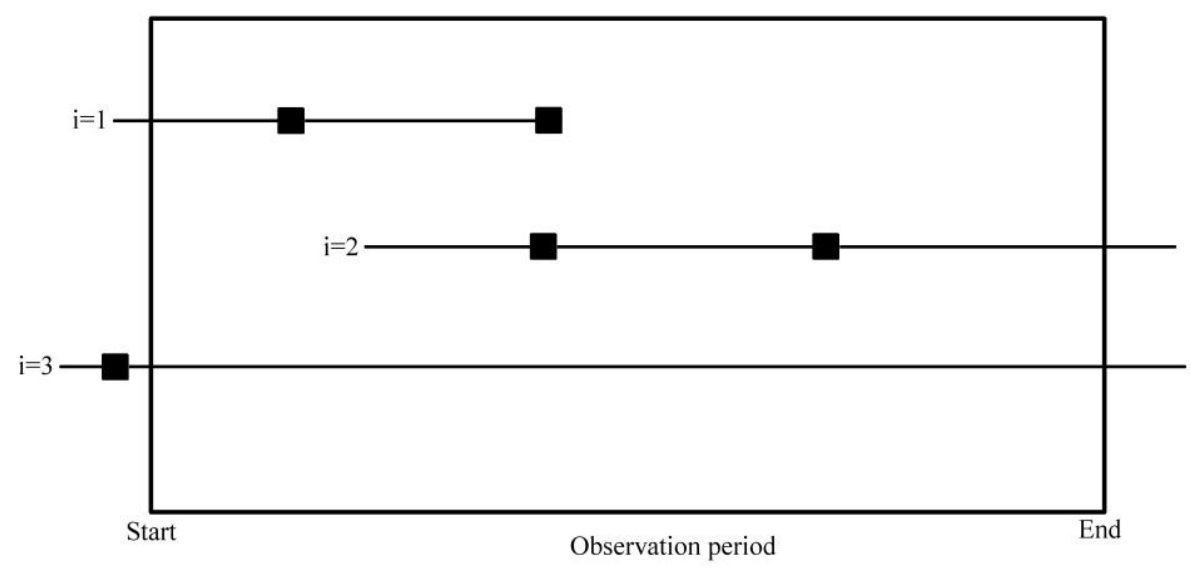

Figure 1 Example of three households with recurrent events Source: own study. 
Our analysis takes into account only the spells that start within the observation period, which means that left-censored data are not included. From the seven waves, the first two are used to construct "inflow" condition. Consequently up to five waves are used for observing poverty exits and entries. For poverty exits, we demand that the household is not-poor in the first period, poor in the second period and from the third period we study whether household exits poverty. The same situation occurs in the case of poverty entries (poor, not-poor and from the third period we observe poverty entries).

\subsection{Data Structure}

As mentioned, in years 2000-2013 households may have several poverty entries and poverty exits. These events are repeatable and therefore we can apply discrete-time multilevel modelling. In our case we have a two-level hierarchical structure with poverty (or nonpoverty) spells (level 1) nested within households (level 2). This structure is illustrated in Figure 2.

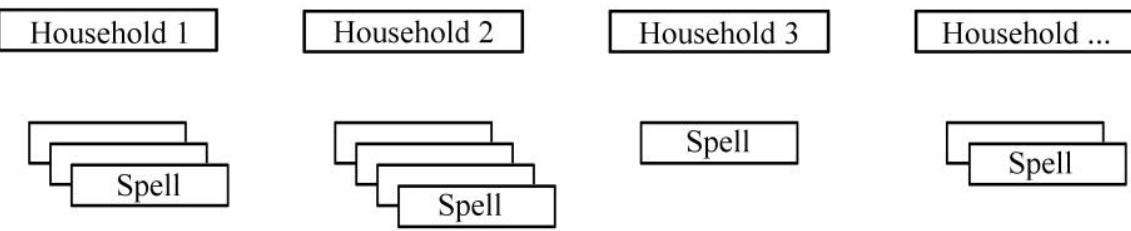

Figure 2 Two-level hierarchical structure for longitudinal data Source: own study based on (Twisk, 2006, 86).

Originally we had data in the form of one record per household. The first step of data transformation is to convert originally data set to a household-spell format with one record for each of $n_{i}$ spells for household $i$. In this file we have information about event time $k$ for household $i\left(t_{i k}\right)$ and censoring indicator:

$$
\delta_{i k}=\left\{\begin{array}{l}
1 \text { if uncensored } \\
0 \text { if censored. }
\end{array}\right.
$$

For a right-censored case, we do not observed $t_{i k}$, but only the time at which they were censored $\left(c_{i k}\right)$. Our outcome variable is therefore $y_{i k}=\min \left(t_{i k}, c_{i k}\right)$ and our observed data are $\left(y_{i k}, \delta_{i k}\right)$.

The second step to conduct discrete-time hazard models is to convert the data into a household-spell-period data format. This conversion process is presented in Table 1. 
Table 1. Data format required for discrete-time survival analysis for recurrent events

Household-spell data set

\begin{tabular}{cccc}
\hline Household $i$ & Spell $k$ & $y_{i k}$ & $\delta_{i k}$ \\
\hline 1 & 1 & 2 & 1 \\
1 & 2 & 4 & 1 \\
1 & 3 & 1 & 0 \\
\hline
\end{tabular}

Household-spell-period data set

\begin{tabular}{cccc}
\hline Household $i$ & Spell $k$ & Period $t$ & $y_{i k t}$ \\
\hline 1 & 1 & 1 & 0 \\
1 & 1 & 2 & 1 \\
1 & 2 & 1 & 0 \\
1 & 2 & 2 & 0 \\
1 & 2 & 3 & 0 \\
1 & 2 & 4 & 1 \\
1 & 3 & 1 & 0 \\
\hline
\end{tabular}

Source: own study.

In household-spell-period file for each record $t=1, \ldots, t_{i k}$ we define a binary indicator $y_{i k t}$ such that:

$$
y_{i k t}=\left\{\begin{array}{l}
1 \text { if episode } k \text { of household } i \text { ends in an event during interval } t \\
0 \text { otherwise. }
\end{array}\right.
$$

All episodes, regardless of whether their duration is censored, will have $y_{i k t}=0$ for intervals $t=1, \ldots, t_{i k}-1$. The response for the last observed interval, $y_{i k t_{k}}$, will be 1 for episodes that end in an event during that interval and 0 for those that are censored at $t_{i k}$.

\section{Results}

Logit models of poverty entries and exits were estimated in two variants. First variant (model 1) concerns only baseline hazard in the form of dummy variables representing the number of periods spent out of poverty (entries analysis) or the number of periods spent in poverty (exits analysis). Second variant (model 2) includes baseline hazard and explanatory variables characterizing household (place of resident and labor status force of household) and household's head (sex, age and education).

First, hazard analysis of poverty entries was conducted. In fact poverty entry was poverty entry ( $1^{\text {st }}$ episode) or poverty re-entry. The sample contained 834 households. Model 1 and model 2 were estimated using MQL-1, PQL-2 and MCMC methods. In both models using MCMC method was produced highly autocorrelated chains. We did not increase the number of iterations. MCMC estimates were close to the PQL-2 estimates and therefore we used PQL-2 for hazard analysis of poverty entries (Table 2). 


\section{$1 \backsim$ APPLICATIONS OF \\ Mathematics and Statistics \\ IN ECONOMICS \\ International Scientific Conference | Poland • 27-31 August 2014}

Table 2. Hazard analysis of poverty entries - estimation results of model 1 (baseline hazard) and model 2 (baseline hazard and explanatory variables) with unobserved heterogeneity

\begin{tabular}{|c|c|c|c|c|}
\hline \multirow[b]{2}{*}{ Variable } & \multicolumn{2}{|c|}{ Model 1} & \multicolumn{2}{|c|}{ Model 2} \\
\hline & Coefficient & $\begin{array}{c}\text { Standard } \\
\text { error }\end{array}$ & Coefficient & $\begin{array}{c}\text { Standard } \\
\text { error }\end{array}$ \\
\hline Poverty entry: & & & & \\
\hline after 1 period of being non-poor & ref & & ref & \\
\hline after 2 periods of being non-poor & $-0,554^{*}$ & 0,172 & $-0,646^{*}$ & 0,300 \\
\hline after 3 periods of being non-poor & $-0,886^{*}$ & 0,281 & $-0,574$ & 0,499 \\
\hline after 4 periods of being non-poor & $-2,138 *$ & 0,728 & $-1,660$ & 1,077 \\
\hline after 5 periods of being non-poor & $-1,927$ & 1,032 & & \\
\hline $\begin{array}{l}\text { Sex of household head: } \\
\text { male }\end{array}$ & & & ref & \\
\hline female & & & 0,221 & 0,242 \\
\hline Age of household head: & & & & \\
\hline below 60 & & & ref & \\
\hline 60 and more & & & $0,951 *$ & 0,279 \\
\hline $\begin{array}{l}\text { Education of household head: } \\
\text { below secondary level }\end{array}$ & & & ref & \\
\hline secondary level and more & & & $-0,836^{*}$ & 0,310 \\
\hline Place of residence: & & & & \\
\hline $\begin{array}{l}\text { urban areas } \\
\text { rural areas }\end{array}$ & & & $\begin{array}{l}-0,592^{*} \\
\text { ref }\end{array}$ & 0,231 \\
\hline $\begin{array}{l}\text { Labor force status of household: } \\
\text { at least one unemployed person } \\
\text { without unemployed person }\end{array}$ & & & $\begin{array}{c}1,125^{*} \\
\text { ref }\end{array}$ & 0,227 \\
\hline Intercept & $-0,906^{*}$ & 0,076 & $-1,660^{*}$ & 0,280 \\
\hline Intercept variance & 0,000 & 0,000 & 0,000 & 0,000 \\
\hline
\end{tabular}

* significance level 0,05

Source: own calculations based on (Council for Social Monitoring, 2014).

In model 1 variables describing duration of being non-poor are statistically significant at the 0,05 level. The hazard of entering poverty declines with the duration non-poor - the highest probability of poverty entry is after one period of being non-poor, the lowest probability is after four periods, i.e. eight years (interval between subsequent waves of panel last two years). There is not significant unobserved heterogeneity between households.

It should be noted that only several households entered poverty after five periods and therefore in model 2 poverty entry after five periods of being non-poor was excluded. In the second model five variables are statistically significant: poverty entry after two periods of being non-poor, age and education of household head, place of resident and labor force status of household. It can be seen that risk of poverty entry decrease for households being non-poor for two periods (relative to households being non-poor for one period), for households living in urban areas (relative to rural areas) and for households whose head have secondary education (relative to below secondary level). Poverty entry increase for households whose 


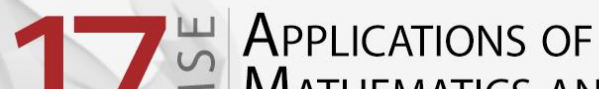 \\ Mathematics and Statistics \\ IN ECONOMICS \\ International Scientific Conference | Poland • 27-31 August 2014}

head is 60 and more and for households with at least one unemployed person. In this model are also no differences between households.

Hazard analysis of poverty exit is shown in Table 3.

Table 3. Hazard analysis of poverty exits - estimation results of model 1 (baseline hazard) and model 2 (baseline hazard and explanatory variables) with unobserved heterogeneity

\begin{tabular}{|c|c|c|c|c|}
\hline \multirow[b]{2}{*}{ Variable } & \multicolumn{2}{|c|}{ Model 1} & \multicolumn{2}{|c|}{ Model 2} \\
\hline & Coefficient & $\begin{array}{c}\text { Standard } \\
\text { error }\end{array}$ & Coefficient & $\begin{array}{c}\text { Standard } \\
\text { error }\end{array}$ \\
\hline Poverty exit: & & & & \\
\hline after 1 period of being poor & ref & & ref & \\
\hline after 2 periods of being poor & $-0,419^{*}$ & 0,184 & $-0,471$ & 0,309 \\
\hline after 3 periods of being poor & $-0,282$ & 0,394 & 0,331 & 0,728 \\
\hline after 4 periods of being poor & $-1,421$ & 0,839 & & \\
\hline $\begin{array}{l}\text { Sex of household head: } \\
\text { male }\end{array}$ & & & ref & \\
\hline female & & & $-0,082$ & 0,240 \\
\hline Age of household head: & & & & \\
\hline below 60 & & & ref & \\
\hline 60 and more & & & $-0,823 *$ & 0,261 \\
\hline $\begin{array}{l}\text { Education of household head: } \\
\text { below secondary level }\end{array}$ & & & ref & \\
\hline secondary level and more & & & $0,863^{*}$ & 0,295 \\
\hline Place of residence: & & & & \\
\hline $\begin{array}{l}\text { urban areas } \\
\text { rural areas }\end{array}$ & & & $\begin{array}{l}0,407 \\
\text { ref }\end{array}$ & 0,216 \\
\hline $\begin{array}{l}\text { Labor force status of household: } \\
\text { at least one unemployed person } \\
\text { without unemployed person }\end{array}$ & & & $\begin{array}{l}-0,823 * \\
\text { ref }\end{array}$ & 0,229 \\
\hline Intercept & $0,505^{*}$ & 0,072 & $1,117 *$ & 0,261 \\
\hline Intercept variance & 0,000 & 0,000 & 0,000 & 0,000 \\
\hline
\end{tabular}

* significance level 0,05

Source: own calculations based on (Council for Social Monitoring, 2014).

Poverty exit was really poverty exit ( $1^{\text {st }}$ episode) or poverty re-exit. We used PQL-2 for hazard analysis of poverty exits (highly autocorrelated chains produced by MCMC method). It can be noticed that none of the surveyed 829 households exited poverty after five periods being poor. In model 1 only poverty exit after one period of being non-poor was statistically significant - the hazard of exiting poverty after two periods was higher than after one period. It has been observed that only a few households exit out of poverty after four periods of being poor - these households were not included in model 2. Better education of household head increases chances for exiting poverty. Older age of household head and unemployed person in household decrease the probability of poverty exit. In model 1 and model 2 there are no differences between households. 


\section{Conclusion}

The purpose of this study was to determine the effect of time spent out of poverty (in poverty) and variables characterizing households and households' head on the probability of poverty entries and exits. The analysis shows negative duration dependence for poverty entries and almost no association between time survived in poverty and poverty exits in Poland in 2000-2013.

Households with one or more unemployed person and households with head 60 and more have a higher risk of poverty entry and at the same time lower chance of poverty exit. Households with less educated head are more at risk of poverty entry and less chance of poverty exit. Households living in urban areas have lower probability of poverty entry and not statistically significant higher probability of poverty exit. Sex of household head does significantly affect to poverty entry and poverty exit.

Identification of households characterized by high probability of poverty entry is very important from the point of view of social policy. On the one hand, actions of the government and non-governmental institutions should be directed to households' groups most at risk of poverty entry in order to avoid poverty transition. On the other hand, social policy should include actions directed to households belonging to poverty for a long time. These households cannot exit from poverty without any additional support and they are most at risk of social exclusion and even biological degradation. It should be noted that determinants of poverty entries and poverty exits in Poland are almost unknown. We could guess that some characteristics of household and household's head may be the determinants of poverty entries and exits. Based on the our study we can point which characteristics are statistically significant determinants.

We should pay attention to data used in analysis. We assumed that belonging to poverty (non-poverty) between subsequent waves of panel do not change, but within two years the situation can change several times. Panel research conducted at shorter intervals should eliminate this weakness and get a full picture of poverty transitions.

\section{References}

1. BROWNE W. J, DRAPER D. 2006. A comparison of Bayesian and likelihood-based methods for fitting multilevel models. In Bayesian Analysis, 2006, vol. 1, no. 3, pp. 473-514.

2. BROWNE W. J., RASBASH J., CHARLTON C. 2012. MCMC Estimation in MLwiN, United Kingdom, 2012. ISBN 978-0-903024-99-0.

3. CALLENS M., CROUX C. 2009. Poverty Dynamics in Europe. A Multilevel Discrete-Time Recurrent Hazard Analysis. In International Sociology, 2009, vol. 24, no. 3, pp. 368-396.

4. COUNCIL FOR SOCIAL MONITORING. 2014. Social Diagnosis 2000-2013: integrated database. [15-01-2014] http://www.diagnoza.com.

5. FRĄTCZAK E., GACH-CIEPIELA U., BABIKER H. 2005. Analiza historii zdarzeń. Elementy teorii, wybrane przykłady zastosowań. Warszawa : SGH, 2006. ISBN 83-7378-138-2.

6. HEDEKER D. 2008. Multilevel models for ordinal and nominal variables. In J. de Leeuw \& E. Meijer (Eds.), Handbook of Multilevel Analysis. New York : Springer, 2008. ISBN 978-0-387-73186-5.

7. ICELAND J. 1997. Urban Labor Markets and Individual Transitions out of Poverty. In Demography, 1997, vol. 34, no. 3, pp. 429-441. 
8. JENKINS S. P. 2004. Survival Analysis. Unpublished manuscript. Institute for Social and Economic Research, University of Essex, Colchester, UK. [02-04-2014] http://www.iser.essex.ac.uk/teaching/degree/stephenj/ec968/pdfs/ec968lnotesv6.pdf.

9. LAWSON A. B., BROWNE W. J., VIDAL RODEIRO C. L. 2003. Disease Mapping with WinBUGS and MLwiN. Chichester : John Wiley \& Sons Ltd, 2003. ISBN 978-0-470-85604-8.

10. McKERNAN S.-M., RATCLIFFE C. 2005. Events that Trigger Poverty Entries and Exits. In Social Science Quarterly, 2005, vol. 86, no. 5, pp. 1146-1169.

11. STEELE F. 2005. Event History Analysis. ESRC National Centre for Research Methods, NCRM Methods Review Papers, NCRM/2004. [02-03-2014] http://eprints.ncrm.ac.uk/88/1/MethodsReviewPaperNCRM-004.pdf.

12. STEELE F. 2008. Multilevel models for longitudinal data. In Journal of the Royal Statistical Society: Series A (Statistics in Society), 2008, vol. 181, iss. 1, pp. 5-19.

13. STEELE F. 2011. Multilevel Discrete-Time Event History Models with Applications to the Analysis of Recurrent Employment Transitions. In Australian \& New Zealand Journal of Statistics, 2011, vol. 53, no. 1, pp. 1-26.

14. STEVENS A. H. 1999. Climbing out of Poverty, Falling Back in: Measuring the Persistence of Poverty over Multiple Spells. In Journal of Human Resources, 1999, vol. 34, no. 3, pp. 557-588.

15. TWISK J. W. R. 2006. Applied Multilevel Analysis. Practical Guides to Biostatistics and Epidemiology. Cambridge : Cambridge University Press, 2006. ISBN 978-0-521-61498-6. 